\title{
Layered Double Hydroxides for Remediation of Industrial Wastewater from a Galvanic Plant
}

\author{
Anna Maria Cardinale ${ }^{1, *}$, Cristina Carbone ${ }^{2}$, Sirio Consani ${ }^{2}$, Marco Fortunato ${ }^{1}$ \\ and Nadia Parodi ${ }^{1}$ \\ 1 Dipartimento di Chimica e Chimica Industriale, Università di Genova, Via Dodecaneso 31, \\ 16146 Genova, Italy; fortunato.marco@hotmail.it (M.F.); nadia@chimica.unige.it (N.P.) \\ 2 Dipartimento di Scienze della Terra, dell'Ambiente e della Vita, Università di Genova, Corso Europa 26, \\ 16132 Genova, Italy; cristina.carbone@unige.it (C.C.); sirio.consani@edu.unige.it (S.C.) \\ * Correspondence: cardinal@chimica.unige.it; Tel.: +39-10-3536156; Fax: +39-10-3536163
}

Received: 3 May 2020; Accepted: 28 May 2020; Published: 30 May 2020

\begin{abstract}
Owing to their structure, layered double hydroxides (LDHs) are nowadays considered as rising materials in different fields of application. In this work, the results obtained in the usage of two different LDHs to remove, by adsorption, some cationic and anionic pollutants from industrial wastewater are reported. The two compounds $\mathrm{MgAl}-\mathrm{CO}_{3}$ and $\mathrm{NiAl}-\mathrm{NO}_{3}$ have been prepared through a hydrothermal synthesis process and then characterized by means of PXRD, TGA, FESEM, and FTIR spectroscopy. The available wastewater, supplied by a galvanic treatment company, has been analyzed by inductively coupled plasma-optical emission spectrometry (ICP-OES), resulting as being polluted by $\mathrm{Fe}(\mathrm{III}), \mathrm{Cu}(\mathrm{II})$, and $\mathrm{Cr}(\mathrm{VI})$. The water treatment with the two LDHs showed that chromate is more efficiently removed by the $\mathrm{NiAl} \mathrm{LDH}$ through an exchange with the interlayer nitrate. On the contrary, copper and iron cations are removed in higher amounts by the MgAl LDH, probably through a substitution with $\mathrm{Mg}$, even if sorption on the $\mathrm{OH}^{-}$functional groups, surface complexation, and/or precipitation of small amounts of metal hydroxides on the surface of the MgAl LDH could not be completely excluded. Possible applications of the two combined LDHs are also proposed.
\end{abstract}

Keywords: layered double hydroxides; wastewater; heavy metals removal

\section{Introduction}

Layered double hydroxides (LDHs) belong to a family of minerals, the so-called hydrotalcite supergroup, whose crystal structure consists of brucite-type layers, in which a trivalent cation partially substitutes a divalent cation [1,2].

This substitution produces a net positive charge balanced by the entrance of an anionic species in the interlayer, giving as a general formula $\mathrm{M}^{2+}{ }_{1-\mathrm{x}} \mathrm{M}^{3+}{ }_{\mathrm{x}}\left(\mathrm{A}^{\mathrm{z}-}\right)_{\mathrm{x} / \mathrm{z}}(\mathrm{OH})_{2} \cdot \mathrm{nH}_{2} \mathrm{O}$.

Their capacity to easily exchange the interlayer anions makes LDHs attractive as carriers or scavengers of potential toxic anions [3-6]. Furthermore, their flexible structure, which can be reproduced using several bivalent and trivalent cations, suggests the possibility to use LDHs as a getter of pollutant cations [7,8]. For all of the above, the knowledge of the relationships between metals and LDHs is fundamental to allow the use of these minerals [9].

In a previous study, the relationships between lanthanides metals and a woodwardite $\left(\mathrm{CuAl}-\mathrm{SO}_{4}\right.$ $\mathrm{LDH}$ ) structure were investigated [10], with the aim to use these materials for the recovery of the rare earth elements from waste electric and electronic equipment for both georemediation and georecovery exploitation. The aim of this work is the synthesis and characterization of two different LDHs to experimentally investigate their capability to recover pollutants from wastewater. Such wastewater has been taken from a galvanic plant. Its composition is enriched in environmentally hazardous anions 
and metal cations, which derive from the treatment process. This problem is widespread [11]. Many different treatments have been proposed to solve this contamination issue [12,13]. In this study, the exchange capability of the two compounds is tested directly on this real wastewater, based on the results previously obtained in a laboratory-prepared $\mathrm{Cr}_{2} \mathrm{O}_{7}{ }^{2-}$ solution [14]. The selected compounds are LDHs, as they represent a cheap and effective method to remove pollutants from aqueous solutions. The two compounds investigated are a NiAl- $-\mathrm{NO}_{3}$ and a $\mathrm{MgAl}-\mathrm{CO}_{3} \mathrm{LDHs}$. The choice of these compositions is based on the fact that previous works have shown the chromate uptake capacity by similar LDHs both intercalated with other sorbents [15] and through an ion exchange reaction with the interlayer anion $[16,17]$.

\section{Materials and Methods}

\subsection{Samples Synthesis}

The compounds were synthesized via the co-precipitation route (direct method), followed by hydrothermal treatment obtaining nanoscopic crystallites with a partially disordered (turbostratic) structure. The addition of urea to the reactants helps to keep the $\mathrm{pH}$ to the desired value and the development of $\mathrm{CO}_{2}$ allows to obtain a high exchange surface structure [15]. Both the LDHs were with the $\mathrm{M}^{2+} / \mathrm{M}^{3+}$ ratio $=2$.

The NiAl- $\mathrm{NO}_{3} \mathrm{LDH}$ was synthesized following the pathway suggested by [18], starting from $\mathrm{Ni}\left(\mathrm{NO}_{3}\right)_{2} \cdot 6 \mathrm{H}_{2} \mathrm{O}\left(99.0 \%\right.$ purity, supplied by Merck KGaA, Darmstadt, Germany), $\mathrm{Al}\left(\mathrm{NO}_{3}\right)_{3} \cdot 9 \mathrm{H}_{2} \mathrm{O}(98.8 \%$ purity, supplied by VWR CHEMICALS, Leuven, Belgium), and urea (99.8mass\% purity, supplied by CARLO ERBA, Milan, Italy). The two salts and urea, in a proper stoichiometric amount, were dissolved in $200 \mathrm{~mL}$ of deionized water under magnetic stirring, then the solution was transferred in a Teflon vessel autoclave and kept at $100^{\circ} \mathrm{C}$ for $24 \mathrm{~h}$. After heating, the system was cooled at room temperature naturally, and the green solid compound obtained was vacuum filtered and washed with water and ethanol. Subsequently, it was dried in a stove at $60^{\circ} \mathrm{C}$ for $24 \mathrm{~h}$. To synthesize the $\mathrm{MgAl}-\mathrm{CO}_{3} \mathrm{LDH}$, as suggested by [19], the reagents $\mathrm{Al}\left(\mathrm{NO}_{3}\right)_{3} \cdot 9 \mathrm{H}_{2} \mathrm{O}(98.8 \%$ purity, supplied by VWR CHEMICALS, Leuven, Belgium), $\mathrm{Mg}\left(\mathrm{NO}_{3}\right)_{2} \cdot 9 \mathrm{H}_{2} \mathrm{O}$ (98.9\% purity, supplied by VWR CHEMICALS, Leuven, Belgium), and urea (99.8 mass\% purity, supplied by CARLO ERBA, Milan, Italy) were used. After the dissolution of the due amount of the reagents, as a function of the $\mathrm{Mg} / \mathrm{Al}$ desired ratio, the reaction was continued in a Teflon vessel autoclave at $180^{\circ} \mathrm{C}$ temperature for one hour. The white compound obtained was separated from the solution by centrifugation at $7000 \mathrm{rpm} 10 \mathrm{~min}^{-1}$, repeatedly washed with water, and dried in a stove at $60^{\circ} \mathrm{C}$ for $24 \mathrm{~h}$.

\subsection{Samples Characterizations}

The compounds were characterized by means of the following techniques: thermo gravimetric analysis (TGA), X-ray diffraction analysis on powders (PXRD), field emission scanning electron microscope analysis (FESEM), Fourier transform infrared spectroscopy (FTIR), and inductively coupled plasma optical emission spectroscopy (ICP-OES) chemical analysis.

\subsubsection{Thermo Gravimetric Analysis}

In order to perform the TGA, about 30-50 mg of the dried powdered LDH was placed in alumina open crucibles; the measurements were carried out by means of a H/LABSYSEVO-1A SETARAM apparatus (Setaram, Caluire, France), at a heating rate of $5{ }^{\circ} \mathrm{C} \mathrm{min}^{-1}$ under argon flux of $30 \mathrm{~mL} \mathrm{~min}{ }^{-1}$.

\subsubsection{Field Emission Scanning Electron Microscope Analysis}

To investigate the morphology and the structure of the synthesized compounds, an FESEM analysis has been performed. The samples were adhered on a conductive resin support, then analyzed by applying an acceleration voltage of $5 \mathrm{kV}$ for $50 \mathrm{~s}$, and a cobalt standard was used for the calibration. 


\subsubsection{Powder X-ray Diffraction}

To determine the crystal structures and to calculate the lattice parameters of the phases, PXRD analysis was carried out by the vertical diffractometer X'Pert MPD (Philips, Almelo, The Netherlands) equipped with a $\mathrm{Cu}$ tube ( $\mathrm{K} \alpha 1$ wavelength: $1.5406 \AA)$. The samples were grounded in an agate mortar. The patterns were collected between $10^{\circ}$ and $100^{\circ} 2 \theta$ with a step of $0.001^{\circ}$ and measuring time of $50 \mathrm{~s} / \mathrm{step}$. The indexing of the obtained diffraction data was performed by a comparison with the literature or calculated data (the program Powder Cell-version1999 [20]).

\subsubsection{FTIR Spectroscopy}

To exclude the possible incorporation during the synthesis of undesirable anions or other species in the interlayer (e.g., $\mathrm{CO}_{2}$ from the atmosphere), FTIR spectroscopy was performed using a Spectrum 65 FT-IR Spectrometer (PerkinElmer, Waltham, MA, USA) equipped with a KBr beamsplitter and a DTGS detector by use of an ATR accessory with a diamond crystal. All spectra were recorded from 4000 to $600 \mathrm{~cm}^{-1}$.

\subsubsection{Inductively Coupled Plasma Optical Emission Spectroscopy}

The chemical analyses were performed by ICP-OES after the dissolution of the samples in the concentrated nitric acid solution.

\subsection{Pollutant Removal from Wastewater}

Based on the results reported in the literature about the adsorption of anions and cations $[7,11]$, in this work the adsorption efficiency of different pollutants (cationic and anionic) was tested on a real industrial wastewater sample. The sample available was analyzed by means of ICP-OES in order to determine the chemical composition of the dissolved elements. The results are the following: $127 \mathrm{ppm}$ $\mathrm{Cu}(\mathrm{II}), 460 \mathrm{ppm} \mathrm{Fe}(\mathrm{III})$, and $8780 \mathrm{ppm} \mathrm{Cr}(\mathrm{VI})$. The $\mathrm{pH}$ value of the wastewater was about 3 . Owing to the very high metals concentration, the sample was diluted to $1 / 100$ with water, before the adsorption tests. The water $\mathrm{pH}$ was corrected at a value of about 5 after dilution, to avoid both the LDH dissolution and the iron hydroxide precipitation. For both the LDHs, a weight of $0.5 \mathrm{~g}$ of the compound was added to a volume of $100 \mathrm{~mL}$ wastewater, and the mixture was shaken for $24 \mathrm{~h}$. The solid and the liquid phases were separated throughout centrifugation at $7000 \mathrm{rpm} 10 \mathrm{~min}^{-1}$, then the solid was repeatedly washed with deionized water. The residual wastewater and the solid phase (after dried and acid dissolution) were analyzed by ICP-OES. After the batch equilibration procedure, the $\mathrm{pH}$ value of the residual wastewater did not change significantly, and no precipitation of iron hydroxide was observed.

\section{Results and Discussions}

The compounds were characterized after synthesis and in Figure 1a,b, their PXRD patterns are reported.

Both diagrams had peculiar features of the presence of the LDH structure, such as the strong basal reflections (003 and 006) around $12^{\circ}$ and $24^{\circ} 2 \theta$, respectively. X-ray data confirm the presence of carbonate and nitrate in the two LDHs. The $\mathrm{MgAl}-\mathrm{CO}_{3} \mathrm{LDH}$ has an interplanar distance associated with the main basal reflection of $7.54 \AA$, which is comparable to those of similar natural and synthetic compounds [1,21], whereas the NiAl- $\mathrm{NO}_{3} \mathrm{LDH}$ has an interplanar distance for the (003) reflection of $7.91 \AA$, as other similar compounds [22]. Comparing the two diagrams, it is also possible to state that the synthesis of the $\mathrm{MgAl}-\mathrm{CO}_{3} \mathrm{LDH}$ yielded a material with a crystallite size significantly higher than the NiAl- $\mathrm{NO}_{3} \mathrm{LDH}$. In fact, the NiAl- $\mathrm{NO}_{3} \mathrm{LDH}$ has broader reflections. Moreover, the PXRD pattern of the NiAl-NO $\mathrm{NO}_{3} \mathrm{LDH}$ shows a doublet in the (006) reflection, coupled with a diffuse and broad (003) reflection. This is probably due to the different hydration state of this LDH, which leads to the presence of crystallites with small differences in the interlayer distance. Water content is well known to 
influence the basal reflection of LDHs, but also the different orientation of nitrate in the interlayer and $\mathrm{M}^{2+} / \mathrm{M}^{3+}$ ratio could explain this effect [23].

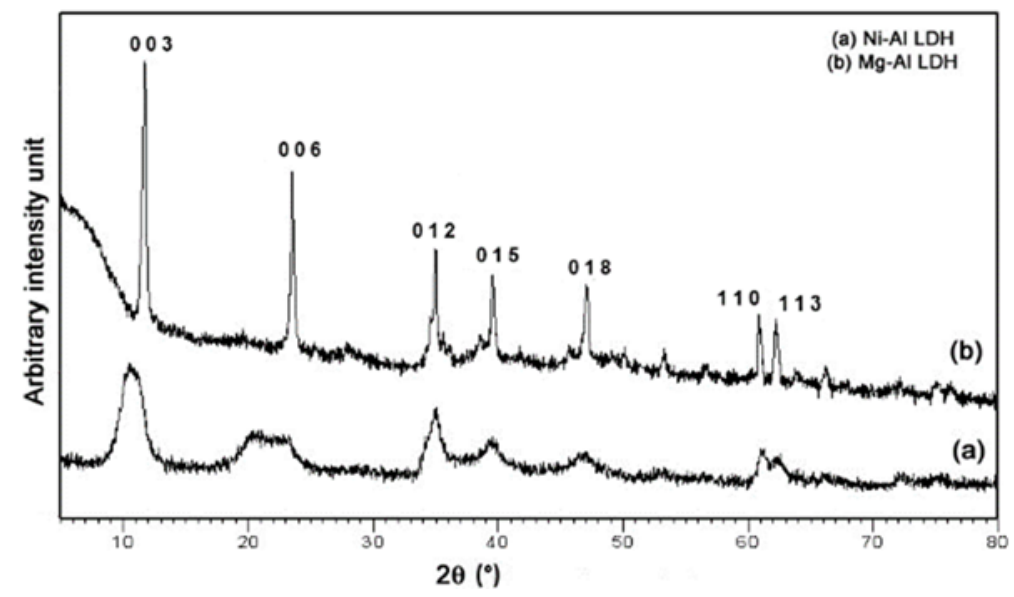

Figure 1. PXRD patterns of (a) NiAl nitrate and (b) MgAl carbonate layered double hydroxides (LDHs). On the graph, the hkl indexes of the main reflections are superimposed.

In Figure 2a,b, the FTIR spectra obtained for the synthesized compounds, the $\mathrm{NiAl}-\mathrm{NO}_{3} \mathrm{LDH}$ and $\mathrm{MgAl}-\mathrm{CO}_{3} \mathrm{LDH}$, respectively, are shown, and the presence of the desired functional groups was confirmed.

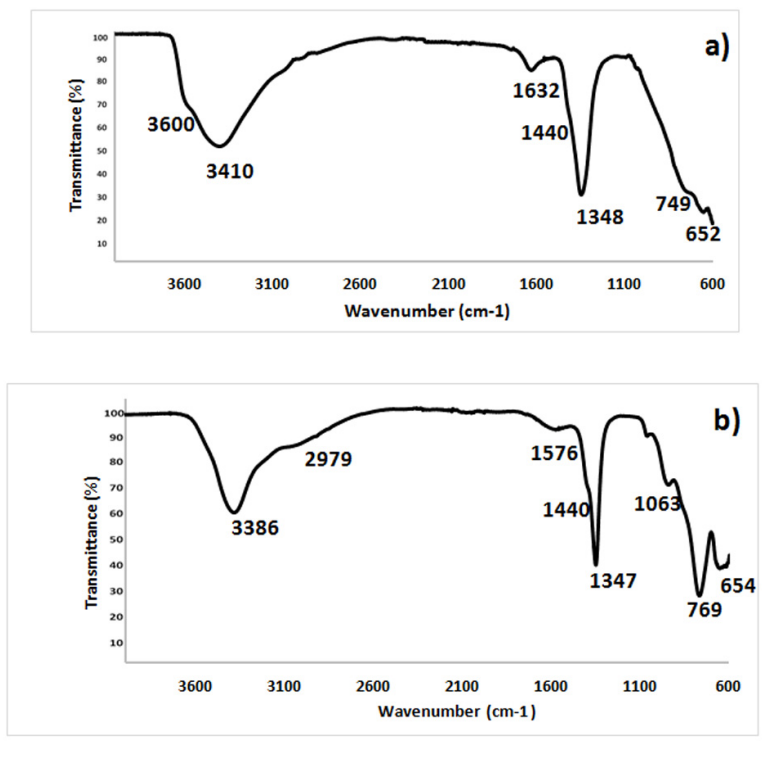

Figure 2. FTIR spectra of (a) the NiAl nitrate LDH, (b) the MgAl carbonate LDH.

Sample (a): A $3600 \mathrm{~cm}^{-1} \mathrm{OH}$ group stretching, $3410 \mathrm{~cm}^{-1}$ hydrogen bond stretching in coordination with the cations, and $1632 \mathrm{~cm}^{-1}$ bending of the $\mathrm{H}_{2} \mathrm{O}$ bond into the interlayer and at $1348 \mathrm{~cm}^{-1} \mathrm{can}$ be found in the nitrate group stretching; the two slight bands at 749 and $652 \mathrm{~cm}^{-1}$ together with the one at $1440 \mathrm{~cm}^{-1}$ partially overlapped with the nitrate bending are related to the undesired interlayer carbonate groups (probably from the atmospheric $\mathrm{CO}_{2}$ ). Sample (b): the broad band at $3386 \mathrm{~cm}^{-1}$ concerns the stretching of the $\mathrm{OH}$ groups in coordination with the cations, at $2979 \mathrm{~cm}^{-1}$ there is the large band related to the $\mathrm{H}$-bonding between the water and carbonate anions in the interlayer, the $1576 \mathrm{~cm}^{-1}$ band originates from the $\mathrm{H}_{2} \mathrm{O}$ bending in the interlayer, and the main carbonate anion adsorption band at $1440 \mathrm{~cm}^{-1}$ is overlapped with the $1347 \mathrm{~cm}^{-1}$ band related to the nitrate group 
stretching; ongoing to the lower frequency at $1063 \mathrm{~cm}^{-1}$, there is the signal due to the carbonate vibration and the two bands at 769 and $654 \mathrm{~cm}^{-1}$ are related to the interlayer carbonate groups.

From these spectra, it seems that in the $\mathrm{MgAl}$ carbonate $\mathrm{LDH}$ there are some impurities of the nitrate anions, while the NiAl LDH is affected by a little impurity of carbonate.

The FESEM images are shown in Figure $3 a, b$, and from the micrographic appearance, the two structures appear similar in morphology, showing the typical hydrotalcite structure, and the thickness of the constituent lamellae was estimated between 10 and $20 \mathrm{~nm}$.
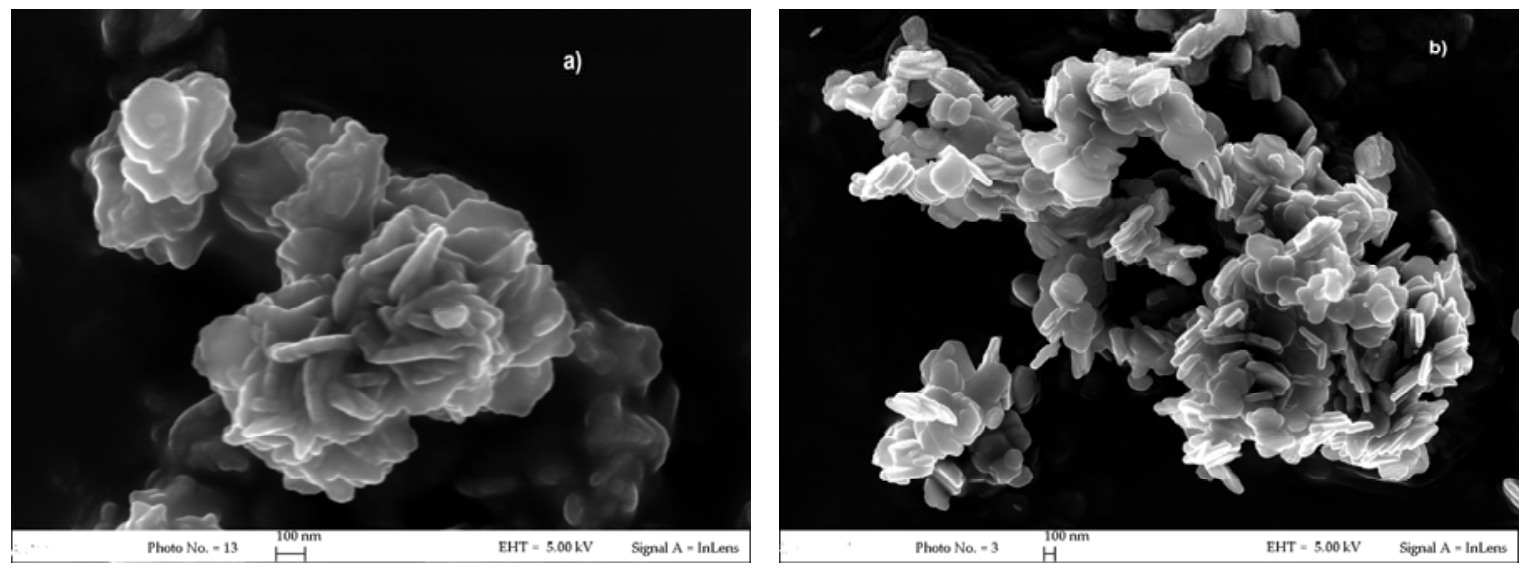

Figure 3. FESEM images of (a) the NiAl-NO $\mathrm{NOH}_{3}$, (b) the $\mathrm{MgAl}-\mathrm{CO}_{3} \mathrm{LDH}$.

For the NiAl-NO $\mathrm{NO}_{3} \mathrm{LDH}$ the specific surface area, calculated by the Brunauer-Emmett-Teller (BET) method, has been measured, resulting in $46.8504 \mathrm{~m}^{2} \mathrm{~g}^{-1}$.

The thermogravimetric analysis, whose results are reported in Figure $4 a, b$, revealed that the NiAl-based LDH (Figure 4a) loses 2.7 mass\% due to humidity at about $150{ }^{\circ} \mathrm{C}$, and has a second mass decreasing at $309.3^{\circ} \mathrm{C}$, involving both the interlayer water and the nitrogen oxide for a whole amount of 24.7 mass\%. The MgAl-based LDH (Figure $4 \mathrm{~b}$ ) loses mass in three steps. The first, due to humidity, at $231{ }^{\circ} \mathrm{C}$ with a mass decrease of 10 mass $\%$, the second ascribable to the removal of the interlayer water $\left(6.5\right.$ mass $\%$ loss at $328^{\circ} \mathrm{C}$ ), and the third of about 16 mass \% was due to the $\mathrm{CO}_{2}$ loss, which started at about $400{ }^{\circ} \mathrm{C}$.
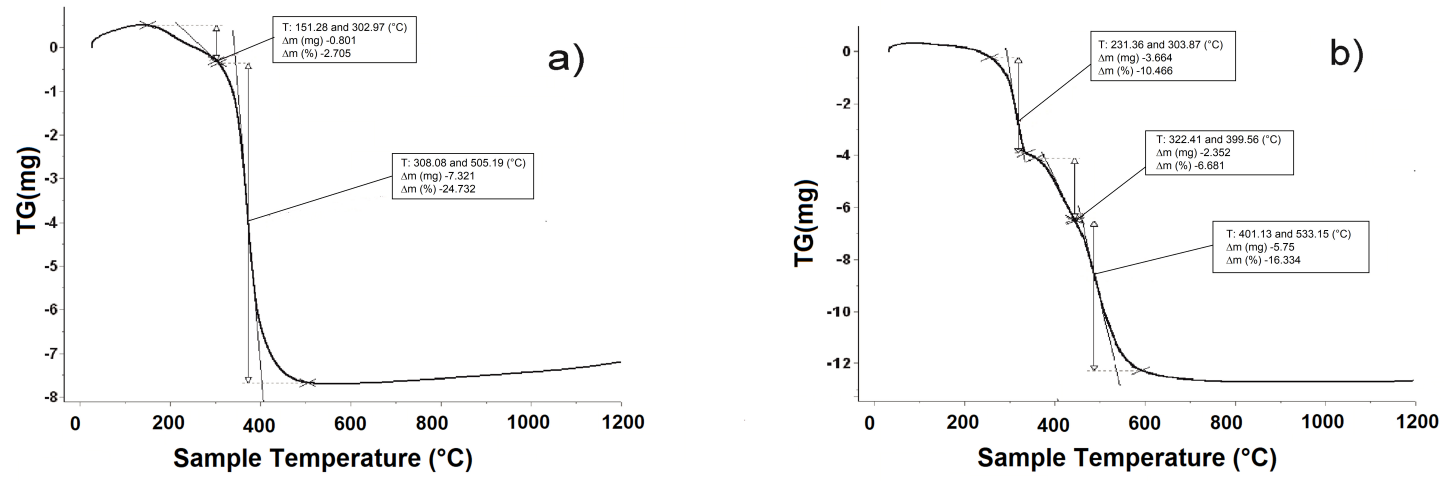

Figure 4. TG thermograms of (a) the NiAl nitrate $\mathrm{LDH}$, (b) the $\mathrm{MgAl}$ carbonate $\mathrm{LDH}$.

As the pollutant removal, both the samples have been kept to a batch equilibration with the wastewater, in the experimental conditions previously described. In Tables 1 and 2, the results obtained for the extraction of copper, iron, and chromium, the three pollutants of the industrial wastewater, are reported. 
Table 1. Pollutant amount in the diluted wastewater before and after treatment with the NiAl- $\mathrm{NO}_{3} \mathrm{LDH}$.

\begin{tabular}{ccccc}
\hline \multirow{2}{*}{ Pollutant } & \multicolumn{3}{c}{ Concentration [ppm] } & \multirow{2}{*}{ Recovery Efficiency } \\
\cline { 2 - 4 } & \multicolumn{2}{c}{ Diluted Water } & LDH & \\
\hline & before treatment & after treatment & after water treatment \\
\hline $\mathrm{Cu}(\mathrm{II})$ & 1.27 & 0.57 & 32 & 25.2 \\
\hline $\mathrm{Fe}(\mathrm{III})$ & 4.60 & 0.51 & 112 & 24.3 \\
\hline $\mathrm{Cr}(\mathrm{VI})$ & 87.8 & 1.18 & 6840 & 77.9 \\
\hline
\end{tabular}

Table 2. Pollutant amount in the diluted wastewater before and after treatment with the $\mathrm{MgAl}-\mathrm{CO}_{3} \mathrm{LDH}$.

\begin{tabular}{ccccc}
\hline \multirow{2}{*}{ Pollutant } & \multicolumn{3}{c}{ Concentration [ppm] } & Recovery Efficiency \\
\cline { 2 - 4 } & \multicolumn{3}{c}{ Diluted Water } & LDH \\
\hline & before treatment & after treatment & after water treatment \\
\hline $\mathrm{Cu}(\mathrm{II})$ & 1.27 & 0.01 & 220.0 & 173 \\
\hline $\mathrm{Fe}(\mathrm{III})$ & 4.60 & 0.02 & 4700.0 & 1021 \\
\hline $\mathrm{Cr}(\mathrm{VI})$ & 87.8 & 62.0 & 2370 & 27 \\
\hline
\end{tabular}

In the tables, the concentration of the three species investigated in the wastewater, before and after the adsorption procedure, and in the solid LDH used to extract the pollutants are shown. The recovery efficiency value expresses the ratio of the element concentration in the LDH to the element concentration in the medium, calculated in each test [24].

The NiAl-NO $\mathrm{NO}_{3}$ compound demonstrated greater affinity for the $\mathrm{CrO}_{4}{ }^{2-}$ anion than for the $\mathrm{Fe}(\mathrm{III})$ and $\mathrm{Cu}(\mathrm{II})$ cations. On the contrary, the $\mathrm{MgAl}-\mathrm{CO}_{3}$ structure did not adsorb significantly the $\mathrm{CrO}_{4}{ }^{2-}$ anion, while it seemed more useful for the two cations.

The chromium adsorption is related to the different exchange capacity of the two anions $\left(\mathrm{CO}_{3}{ }^{2-}\right.$ and $\mathrm{NO}_{3}{ }^{-}$) in the interlayers, where nitrate can be easily substituted by chromate, as confirmed from the PXRD. The comparison between the position of the three main reflections of the compound before and after the chromium extraction from the water are reported in Figure 5. The shift of the main basal reflections of the NiAl LDH toward lower $2 \theta$ values (Figure 5a) indicates an enlargement of the interlayers due to the substitution of $\mathrm{NO}_{3}{ }^{-}$with $\mathrm{CrO}_{4}{ }^{2-}$. This shift is reflected in a change in the cell parameter $c$ (calculated as $c=3 \times \mathrm{d}_{(003)}$ ), which changed from 23.85 to $24.99 \AA$, caused by the swelling of the interlayer due to the $\mathrm{NO}_{3}{ }^{-}$with $\mathrm{CrO}_{4}{ }^{2-}$ substitution. The low crystallinity of the samples prevented to meaningfully discuss the cell parameter $a$, calculated as $a=2 \times \mathrm{d}_{(110)}$.

The values of the cell parameter $c$ of the $\mathrm{MgAl}-\mathrm{CO}_{3} \mathrm{LDHs}$ before and after the experiment are 22.71 and $22.56 \AA$, respectively. This fact suggests that little changes took place in the interlayer of these LDHs, as confirmed by Figure $5 \mathrm{~b}$. The high affinity of the $\mathrm{MgAl}-\mathrm{CO}_{3} \mathrm{LDH}$ for the two cations is worthy of further study, but as for copper, it seems to be imputable to an exchange between the copper and magnesium divalent cations due to the similar ionic radius values of the two elements in octahedral coordination (72 and $73 \mathrm{pm}$, respectively). No significant change in the $a$ parameter before and after the experiment is observed, as its value remains constant at 3.04 A. Probably, the disordered nature of the cation arrangement in the brucite-like layers prevents the observation of the changes in the $a$ parameter [2]. The $\mathrm{Cu}-\mathrm{Mg}$ substitution has already been proposed for $\mathrm{MgAl} \mathrm{LDHs}$ in contact with solutions in which bivalent cations are dissolved [25], even if sorption on the $\mathrm{OH}^{-}$functional groups, surface complexation, and/or precipitation of small amounts of $\mathrm{Me}(\mathrm{OH})_{2}$ on the surface of the MgAl LDH could not be completely excluded [9]. Regarding iron adsorption, the characterization analysis did not provide precise information on where it might have accumulated It is possible that Fe has been removed via interaction with the functional groups on the surface of the mineral. 

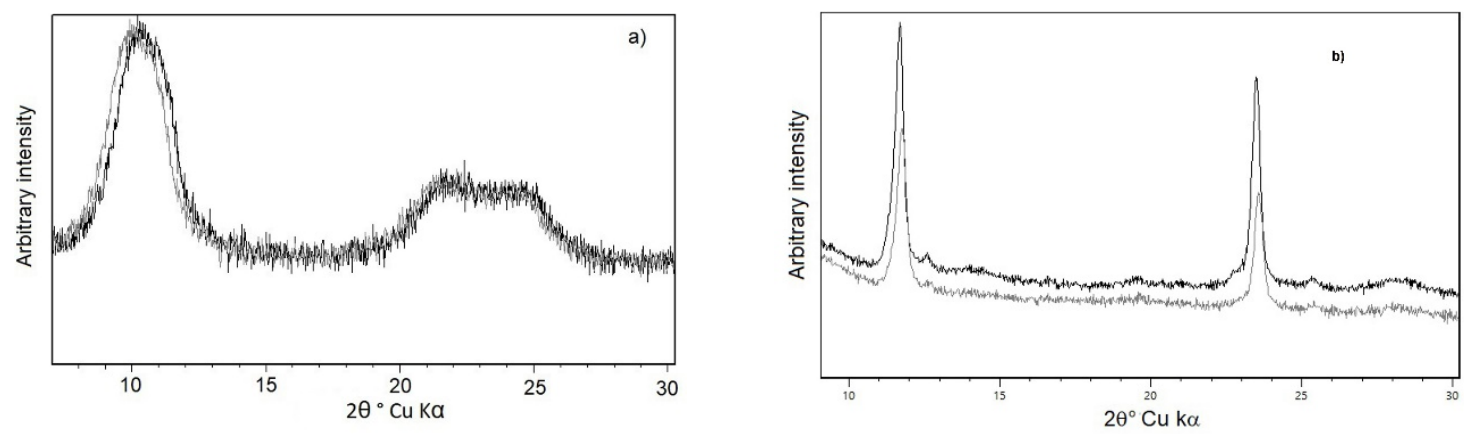

Figure 5. PXRD for (a) the NiAl nitrate LDH before (dark grey) and after (light grey) pollutant removal from the wastewater and (b) the $\mathrm{MgAl}$ carbonate LDH before (dark grey) and after (light grey) pollutant removal from the wastewater.

\section{Conclusions}

The experimental results obtained lead to the following conclusions:

- The LDHs' syntheses are relatively easy to prepare, leading to the required products as shown by the characterization analyses conducted;

- $\quad$ As the tested LDHs:

- The NiAl- $-\mathrm{NO}_{3}$ compound demonstrates greater affinity for the $\mathrm{CrO}_{4}{ }^{2-}$ anion than for the $\mathrm{Fe}(\mathrm{III})$ and $\mathrm{Cu}(\mathrm{II})$ cations;

- The $\mathrm{MgAl}-\mathrm{CO}_{3}$ structure does not significantly adsorb the $\mathrm{CrO}_{4}{ }^{2-}$ anion, while it seems more effective for the two cations;

- By comparing the residual concentration of the three elements studied with the Italian legal limit for industrial wastewater, reported in Table 3, with respect to the disposal in superficial water or in the drainage system:

Table 3. Italian legal concentration limit for chromium (VI), iron, and copper for disposal in both superficial water and drainage systems. (All. 5, P. Terza, D. Lgs n.152 del 03-04-06).

\begin{tabular}{ccc}
\hline Element & Superficial Water/ppm & Drainage System/ppm \\
\hline $\mathrm{Cu}(\mathrm{II})$ & 0.1 & 0.4 \\
\hline $\mathrm{Fe}(\mathrm{III})$ & 2.0 & 4.0 \\
\hline $\mathrm{Cr}(\mathrm{VI})$ & 0.2 & 0.2 \\
\hline
\end{tabular}

The NiAl-NO $\mathrm{NO}_{3}$ compound reduces the $\mathrm{Cr}(\mathrm{VI})$ content at a value close to the legal limit, but is not sufficiently low. Some improvements of the methods (reaction time, sorbent/wastewater ratio) could help in reaching the goal.

The $\mathrm{MgAl}-\mathrm{CO}_{3} \mathrm{LDH}$ demonstrates to be very effective in lowering the $\mathrm{Cu}(\mathrm{II})$ and $\mathrm{Fe}(\mathrm{III})$ concentration to below the legal limit.

For all of the above, the next step will be to test the effectiveness of a combined use of the two metal getters and their transformation into a spinel-like structure after heating for a potential reuse.

Author Contributions: Conceptualization: A.M.C., C.C.; investigation: A.M.C., S.C., M.F., N.P.; methodology: A.M.C., S.C.; writing-original draft preparation: A.M.C., S.C.; writing-review and editing: A.M.C., S.C.; resources: A.M.C., C.C. All authors have read and agreed to the published version of the manuscript.

Funding: This research received no external funding.

Conflicts of Interest: The authors declare no conflict of interest. 


\section{References}

1. Mills, S.J.; Christy, A.G.; Génin, J.-M.R.; Kameda, T.; Colombo, F. Nomenclature of the hydrotalcite supergroup: Natural layered double hydroxides. Miner. Mag. 2012, 76, 1289-1336. [CrossRef]

2. Evans, D.G.; Slade, R.C.T. Layered Double Hydroxides; Duan, X., Evans, D.G., Eds.; Springer: Berlin/Heidelberg, Germany, 2006; Chapter 1; pp. 1-87. ISBN 978-3-540-28279-2.

3. Wang, Y.; Gao, H. Compositional and structural control on anion sorption capability of layered double hydroxides (LDHs). J. Colloid Interface Sci. 2006, 301, 19-26. [CrossRef] [PubMed]

4. Morimoto, K.; Anraku, S.; Hoshino, J.; Yoneda, T.; Sato, T. Surface complexation reactions of inorganic anions on hydrotalcite-like compounds. J. Colloid Interface Sci. 2012, 384, 99-104. [CrossRef]

5. Golban, A.; Lupa, L.; Cocheci, L.; Rodica, P. Synthesis of MgFe Layered Double Hydroxide from Iron-Containing Acidic Residual Solution and Its Adsorption Performance. Crystals 2019, 9, 514. [CrossRef]

6. Dore, E.; Frau, F.; Cidu, R. Antimonate Removal from Polluted Mining Water by Calcined Layered Double Hydroxides. Crystals 2019, 9, 410. [CrossRef]

7. Mishra, G.; Dash, B.; Pandey, S. Layered double hydroxides: A brief review from fundamentals to application as evolving biomaterials. Appl. Clay Sci. 2018, 153, 172-186. [CrossRef]

8. Tamzid Rahman, M.; Kameda, T.; Kumagai, S.; Yoshioka, T. A novel method to delaminate nitrate-intercalated $\mathrm{MgAl}$ layered double hydroxides in water and application in heavy metals removal from waste water. Chemosphere 2018, 203, 281-290. [CrossRef]

9. Liang, X.; Zang, Y.; Xu, Y.; Tan, X.; Hou, W.; Wang, L.; Sun, Y. Sorption of metal cations on layered double hydroxides. Colloids and Surfaces A: Physicochem. Eng. Asp. 2013, 433, 122-131. [CrossRef]

10. Consani, S.; Balić-Žunić, T.; Cardinale, A.M.; Sgroi, W.; Giuli, G.; Carbone, C. A Novel Synthesis Routine for Woodwardite and Its Affinity towards Light ( $\mathrm{La}, \mathrm{Ce}, \mathrm{Nd})$ and Heavy (Gd and Y) Rare Earth Elements. Materials 2018, 11, 130. [CrossRef]

11. Zinicovskaia, I.; Safonov, A.V.; Khijniak, T.V. Heavy Metals and Other Pollutants in the Environment: Biological Aspects; Zaikov, G.E., Weisfeld, L.I., Lisitsyn, E.M., Bekuzarova, S.A., Eds.; Apple Academic Press: Waretown, NJ, USA, 2017; Chapter 17; pp. 333-360. ISBN 978-1-315-36602-9.

12. Kobya, M.; Erdem, N.; Demirbas, E. Treatment of Cr, Ni and Zn from galvanic rinsing wastewater by electrocoagulation process using iron electrodes. Desalin. Water Treat. 2014, 56, 1191-1201. [CrossRef]

13. Bednarik, V.; Vondruska, M.; Koutny, M. Stabilization/solidification of galvanic sludges by asphalt emulsions. J. Hazard. Mat. 2005, B122, 139-145. [CrossRef] [PubMed]

14. Goswamee, R.L.; Sengupta, P.; Bhattacharyya, K.G.; Dutta, D.K. Adsorption of Cr(VI) in layered double hydroxides. Appl. Clay Sci. 1998, 13, 21-34. [CrossRef]

15. Chen, S.; Huang, Y.; Han, X.; Wu, Z.; Lai, C.; Wang, J.; Deng, Q.; Zeng, Z.; Deng, S. Simultaneous and efficient removal of $\mathrm{Cr}(\mathrm{VI})$ and methyl orange on LDHs decorated porous carbons. Chem. Eng. J. 2018, 352, 306-315. [CrossRef]

16. Chao, H.-P.; Wang, Y.-C.; Tran, H.N. Removal of hexavalent chromium from groundwater by Mg/Al-layered double hydroxides using characteristics of in-situ synthesis. Environ. Pollut. 2018, 243, 620-629. [CrossRef]

17. Lei, C.; Zhu, X.; Zhu, B.; Jiang, C.; Le, Y.; Yu, J. Superb adsorption capacity of hierarchical calcined Ni/Mg/Al layered double hydroxides for Congo red and Cr(VI) ions. J. Hazard. Mat. 2017, 321, 801-811. [CrossRef]

18. Liu, H.; Yu, T.; Su, D.; Tang, Z.; Zhang, J.; Liu, Y.; Yuan, A.; Kong, Q. Ultrathin NiAl layered double hydroxide nanosheets with enhanced supercapacitor performance. Ceram. Int. 2017, 43, 14395-14400. [CrossRef]

19. Rao, M.M.; Reddy, B.R.; Jayalakshmi, M.; Jaya, V.S.; Sridhar, B. Hydrothermal synthesis of Mg-Al hydrotalcites by urea hydrolysis. Mat. Res. Bull. 2005, 40, 347-359. [CrossRef]

20. Kraus, W.; Nolze, G. Powder Cell for Windows; Federal Institute for Materials Research and Testing: Berlin, Germany, 1999.

21. Somosi, Z.; Muráth, S.; Nagy, P.; Sebők, D.; Szilagyi, I.; Douglas, G. Contaminant removal by efficient separation of in situ formed layered double hydroxide compounds from mine wastewaters. Environ. Sci. Water Res. Technol. 2019, 5, 2251-2259. [CrossRef]

22. Ravuru, S.S.; Jana, A.; De, S. Synthesis of NiAl- layered double hydroxide with nitrate intercalation: Application in cyanide removal from steel industry effluent. J. Hazard. Mater. 2019, 373, 791-800. [CrossRef]

23. Marappa, S.; Radha, S.; Kamath, P.V. Nitrate-intercalated layered double hydroxides—Structure model, order, and disorder. Eur. J. Inorg. Chem. 2013, 2013, 2122-2128. [CrossRef] 
24. Jakubiak, M.; Giska, I.; Asztemborska, M.; Bystrzejewska-Piotrowska, G. Bioaccumulation and biosorption of inorganic nanoparticles: Factors affecting the efficiency of nanoparticle mycoextraction by liquid-grown mycelia of Pleurotus eringi and Trametes versicolor. Mycol. Progress. 2013, 13, 525-532. [CrossRef]

25. González, M.A.; Pavlovic, I.; Barriga, C. $\mathrm{Cu}(\mathrm{II}), \mathrm{Pb}(\mathrm{II})$ and $\mathrm{Cd}(\mathrm{II})$ sorption on different layered double hydroxides. A kinetic and thermodynamic study and competing factors. Chem. Eng. J. 2015, 269, 221-228. [CrossRef]

(C) 2020 by the authors. Licensee MDPI, Basel, Switzerland. This article is an open access article distributed under the terms and conditions of the Creative Commons Attribution (CC BY) license (http://creativecommons.org/licenses/by/4.0/). 